\title{
Polimerszálak előállítása PET-palackból elektrosztatikus szálképzéssel
}

\section{Electrospinning of Polymer Fibres Using Recycled PET}

\author{
Gergely Attila, ${ }^{1}$ Kántor József, ${ }^{2}$ Bitay Enikő,, ${ }^{3}$ Biró Domokos ${ }^{5}$ \\ ${ }^{1}$ Sapientia Erdélyi Magyar Tudományegyetem, Marosvásárhelyi Kar, Gépészmérnöki Tanszék, \\ Marosvásárhely, Románia, agergely@ms.sapientia.ro \\ ${ }^{2}$ Elitex Prodexim Kft., Mezőcsávás, Románia, jkantor106@gmail.com \\ ${ }^{3}$ Sapientia Erdélyi Magyar Tudományegyetem, Marosvásárhelyi Kar, Gépészmérnöki Tanszék, \\ Marosvásárhely, Románia \\ ${ }^{4}$ Erdélyi Múzeum-Egyesület Kutatóintézet, Kolozsvár, Románia, bitay@eme.ro \\ ${ }^{5}$ Sapientia Erdélyi Magyar Tudományegyetem, Marosvásárhelyi Kar, Gépészmérnöki Tanszék, \\ Marosvásárhely, Románia, dbiro@ms.sapientia.ro
}

\begin{abstract}
The recycling of polymer materials is still unresolved to this day, and this has devastating effect on the environment. This study examines an alternative method to PET recycling that is the generation of polymer fibres and fibre mats for filtration applications. The electrospinning instrumentation used in this study, had to be designed and built, in order to carry out the research. We have managed to produce PET fibres with 200-600 $\mathrm{nm}$ diameter, and free-standing fibre mats that could potentially be used in filtration applications.
\end{abstract}

Keywords: polymer fiber, electrospinning, recycling, PET.

\section{Összefoglalás}

A polimer anyagok újrahasznosítása napjainkig megoldatlan probléma, mely nagymértékben hat a környezetre. A tanulmány a PET-palackok újrahasznosításának egy potenciális formáját mutatja be, mely szürőberendezésekhez alkalmas membránok előállítása PET-palackokból elektrosztatikus szálképzési eljárással. A tanulmány a szálképzés technológiai paramétereinek hatását vizsgálta a keletkezett polimerszálak átmérőjére. A kutatáshoz szükséges berendezés elkészítése után 200-600 nm átmérőjü polimerszálakat, illetve összefüggő membránokat sikerült létrehozni.

Kulcsszavak: polimerszál, szálképzés, újrahasznosítás, PET.

\section{Bevezető}

A poli(etilén-tereftalát) (PET) palackok újrahasznosítása égető probléma, mivel szinte kizárólag ezt az anyagot használják víz és különböző üdítők palackozására. 2012-ben az Amerikai Egyesült Államokban a szemét 12,7\%-át a polimer anyagok tették ki [1, 2]. Az összes polimerhulladék 9\%-a volt újrahasznosítva, aminek 30\%-át PET-palackok tették ki [3]. Az újrahasznosított PET anyagot felhasználják autóalkatrészek gyártásában, csomagolóanyagként, tárolóegységekben, különféle textilekben és fóliákban [4]. Emellett a tiszta
PET anyagot alkalmazzák védőruházat, membránok, orvosi felszerelések és szűrőbetétek alapanyagaként [5, 6].

A palackokhoz használt PET részben kristályos szerkezetű, nagyon jók a szilárdság jellegű mechanikai tulajdonságai, ellenáll a környezeti hatásoknak, illetve $70^{\circ} \mathrm{C}$ hőmérsékletig megőrzi alakját [7, 8]. Az újrahasznosított PET, mivel több anyaggal érintkezett a gyártás és a felhasználás folyamán, nem alkalmas orvosi alkalmazások kifejlesztésére. Figyelembe véve a levegőszennyezés növekedését [9] és a PET mechanikai tulajdonságait [10], 
az újrahasznosított PET használata szürőberendezések kifejlesztésében igen hasznosnak bizonyulhat.

Polimer szűrőberendezések létrehozásához polimerszálakat kell képezni. Nano- és mikrométer nagyságrendű átmérőjű polimerszálakat - többek között - elektrosztatikus szálképzési eljárással lehet előállítani. Ennek is két típusa van: az egyik típus polimerolvadékot használ fel a szálképzéshez, a másik típus polimeroldatot [11]. Az első variáns, az ömledékes szálképzés, angolul „melt spinning” néven ismert a szakirodalomban. Ezen eljárás hátrányai közé tartozik a nagy energiaszükséglet, mely a polimerolvadék előállításához szükséges, a nem megfelelő kontroll a polimerszálak méretét tekintve, illetve az, hogy relatíve nagy átmérőjű szálakat eredményez (mikrométer nagyságrendű) [12]. Újrahasznosított PET-ből ezzel az eljárással $30 \mu \mathrm{m}$ átmérőjü szálak előállítását valósították meg [8]. Az oldatos szálképzési eljárások révén nyert polimerszálak mérete viszont nagyon jól kontrollálható [10].

$\mathrm{Az}$ 1. ábra a szálképző berendezés vázát mutatja. A berendezésnek 3 fô komponense van: egy egyenáramú, nagyfeszültségű tápegység, egy tartály, mely a polimeroldatot tartalmazza és egy kis átmérőjű nyílása van, valamint egy kollektor, mely a polimerszálak felfogására szolgál. Az elektrosztatikus szálképzésnél a nagyfeszültségű tápegység által létrehozott villamos tér segíti elő az elektrosztatikusan töltött polimer folyadék-

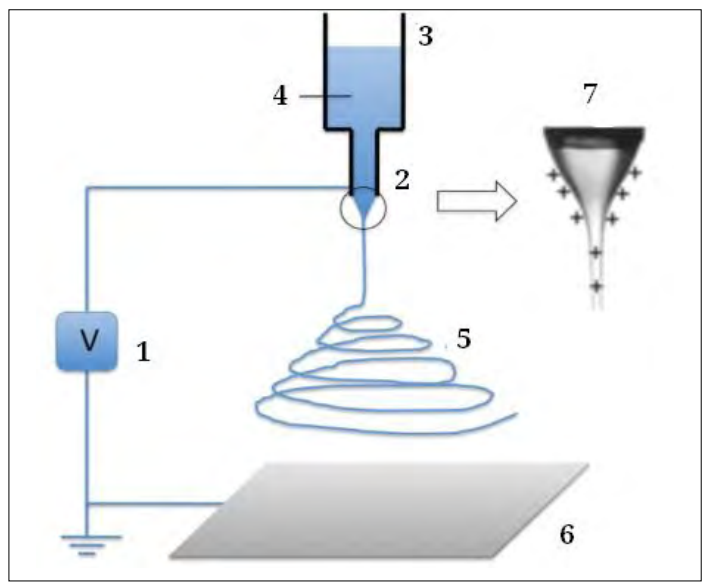

1. ábra. Polimerszálak előállítása elektrosztatikus szálképzéssel polimeroldatból [14]. 1: nagyfeszültségü tápegység, 2: szálképző elektróda (kapilláris), 3: oldatadagoló, 4: szálképzési folyadék, 5: szálképzési térrész, 6: szálgyüjtő (földelt), 7: Taylor-kúp, vagyis a kapillárisból kilépő folyadék deformált alakja sugár létrehozását. Mielőtt a folyadéksugár a kollektorra érne, az oldószer elpárolog, és a kollektoron a megszilárdult, nano-/mikrométer átmérőjü polimerszálak porózus filcet képeznek, melyet a 2. ábra szemléltet [11, 13].

A polimeroldatot tartalmazó tartályból, amely az esetek nagy többségében egy fecskendő, egy csövezeten keresztül jut el az oldat a fecskendő végén található tűbe. A tủ pozitív, míg a kollektor negatív vagy földpotenciálra van kapcsolva. A polimeroldatban a pozitív potenciál hatására pozitív töltések jelennek meg. A pozitív töltések a polimeroldatban taszítják egymást. A feszültség növelésével a pozitív töltések közti taszítóerő tovább növekszik. A folyadéksugár létrejön, amikor a töltések közti taszítóerő meghaladja az oldat felületi feszültségét a tű hegyén található folyadékcsepp felszínén. Az 1. ábra mutatja az ún. Taylor-kúpot is, mely a tű végén alakul ki [15]. Amíg a polimeroldat a tű hegyétől a kollektorig elér, az oldószer nagy része elpárolog és a szál megnyúlik, így képezve az akár nanométer nagyságrendű átmérőt $[11,13]$.

Strain és mtsai [10] újrahasznosított PET-oldatából, az elektrosztatikus szálképzéssel polimerszálakat és filcet készített. Coca-Cola palackokat, valamint trifluor-ecetsavat és diklór-metánt használtak fel a polimeroldat elkészítéséhez. A szálképzés technológiai változói a következők voltak: a tű és a kollektor közti távolság $250 \mathrm{~mm}$, a tü belső átmérője 0,6 mm, a polimeroldat térfogatárama 5, 10 és $20 \mu \mathrm{l} / \mathrm{min}$ között változott, ami magával vonta a potenciálkülönbség változtatását 7 és 12 kV között, továbbá a polimeroldat koncentrációját változtatták 10, 15 és 20 tömegszázalék közt. A szálképzés eredményeként átlagosan 0,4-4,3 $\mu \mathrm{m}$ átmérőjü szálakat kaptak. Az eredmények alapján kimondható, hogy minél kisebb a polimeroldat koncentrációja, annál vékonyabb szálakat eredményez az eljárás. A szerzők a szálak alkotta filcből szűrőt készítettek, melyet cigarettafüst szürésére használtak fel. Az eredmények szerint a szűrés után a 0,4 $\mu \mathrm{m}$ átmérőjű szálakból kialakított polimerszűrők tömege 43-szorosa volt a szürés előtti tömegüknek. Ez az eredmény nagyszerűen bizonyítja az újrahasznosított PET létjogosultságát a levegőszűrési eljárásban. A tanulmány konklúziójaként Strain és mtsai megemlíti, hogy minél kisebb a polimerszálak átmérője, annál kedvezőbbek a mechanikai és szürési tulajdonságai a polimerszűrőnek [10]. 2015 óta már többen követik munkájukat: 21 hivatkozás van a publikációra a Google Scholar alapján, köztük olyan is, amely a szálképzéssel újrahasz- 
nosított PET vízszürési célra való felhasználását ismerteti [16].

Strainék munkája nagyszerüen bizonyítja az újrahasznosított PET anyagok létjogosultságát a szürési technológiában, viszont hiányzik egy szisztematikus tanulmány, amely az elektrosztatikus szálképzés technológiai változóit az előállított szál, illetve filc minőségéhez köti.

A fentiek alapján a jelen tanulmány célja egy szisztematikus méréssorozat ismertetése, mely a polimeroldat koncentrációja, térfogatárama, az alkalmazott potenciálkülönbség, a tű és a kollektor közti távolság, a tű belső átmérője mint technológiai tényezők és a létrejött polimerszál minősége közötti kapcsolatot elemzi.

\section{Módszertan}

\subsection{A polimeroldat}

A kísérletekhez a Carpatica ásványvíz átlátszó PET-palackját használtuk fel. A palackot etanollal megtisztítottuk a szennyeződésektől, majd kb. 10×10 $\mathrm{mm}^{2}$-es négyzeteket vágtunk belőle. A kívánt koncentrációhoz szükséges PET kimérése után, megfelelő mennyiségű trifluor-ecetsavval keverve rázópadra helyeztük 400 ford./percen. A koncentráció függvényében a PET 15-90 perc alatt teljesen feloldódott az oldószerben.

\subsection{A szálképzési eljárás}

A szálképzést a megépített szálképző berendezés segítségével valósítottuk meg. A szálképzési folyamat megkezdéséhez az oldatot 5 ml-es fecskendőbe helyeztük. A fecskendőt és a kívánt belső átmérőjü tűt 1/16” belső átmérőjü tefloncsővel csatlakoztattuk. A fecskendőt a fecskendőpumpába helyeztük, a tűt pedig a szálképző berendezés oszlopos részén az erre kialakított tartóra rögzítettük. A tüt a nagyfeszültségű tápegység pozitív pólusára, a kollektort pedig a földpotenciálra csatlakoztattuk. A szálképzési folyamat 8 percig tartott.

\subsection{Pásztázó elektronmikroszkópos vizsgá- lat}

A pásztázó elektronmikroszkópos vizsgálat egy JEOL JSM-5200 berendezésen volt kivitelezve. A minták $10 \mathrm{kV}$ feszültségen 1000, 5000 és 10000-szeres nagyításon voltak vizsgálva. A 10000-szeres nagyítású képek a minta három különböző pontjáról készültek.

A polimerszálak átmérőjének meghatározására az ImageJ programot használtuk. Minden 10000-szeres nagyítású képen legalább 10 mérést végeztünk a PET-szálak átmérőjének meghatáro- zása érdekében. Azokban az esetekben, amikor gömbök is keletkeztek a szálképzési folyamat során, minimum 30 gömböt mértünk meg.

\section{Eredmények}

\subsection{A szálképző berendezés tervezése és kivitelezése}

A szálképző berendezés tervezésekor a szempont egy egyszerűen kivitelezhető, flexibilis rendszer megalkotása volt. A megépített berendezés a 2. ábrán látható.

A fecskendőpumpát a külső állványra szereltük oly módon, hogy a tű fölött helyezkedjen el. A fecskendő a fecskendőpumpába befogva található, míg a tű az erre a célra kialakított tartón helyezkedik el. A fecskendőt és az injekciós tűt egy csővezeték köti össze. A kollektor a tű alatt helyezkedik el, a kívánt távolságra. A képen nem látható nagyfeszültségű tápegység, amelynek a pólusaihoz csatlakoztatva kapcsoljuk a tűt pozitív és a kollektort földpotenciálra, létrehozva a folyamathoz szükséges elektromos teret.

A 3. ábrán látható egy ún. porózus polimermembrán, valamint annak pásztázó elektronmikroszkóppal készített képe. Megfigyelhető, hogy a

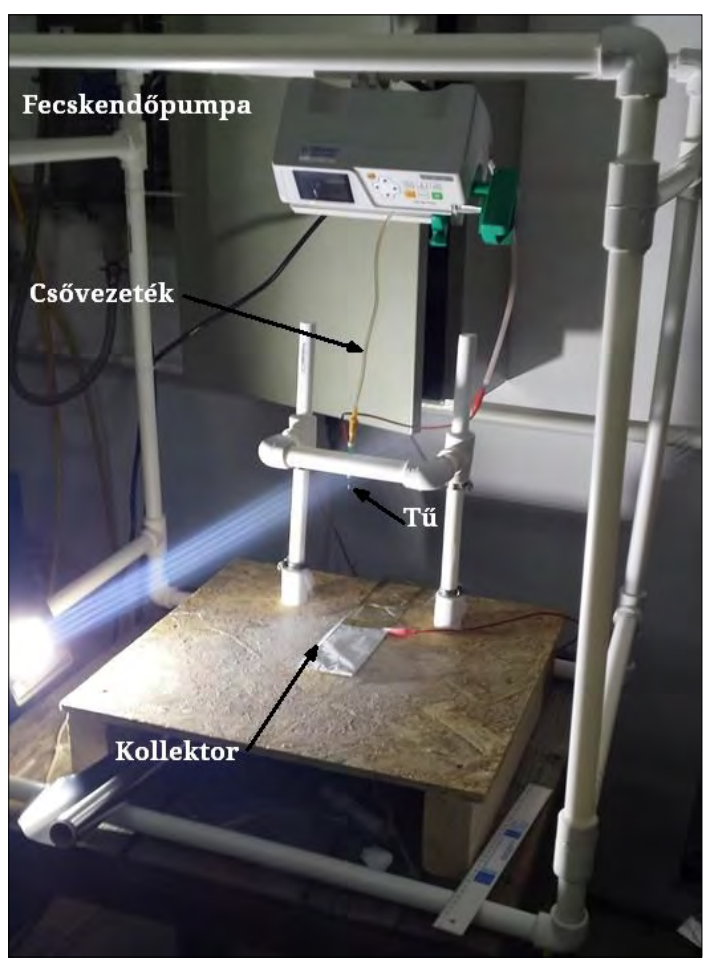

2. ábra. A kutatás eredményeként megépített elektrosztatikus szálképző berendezés 


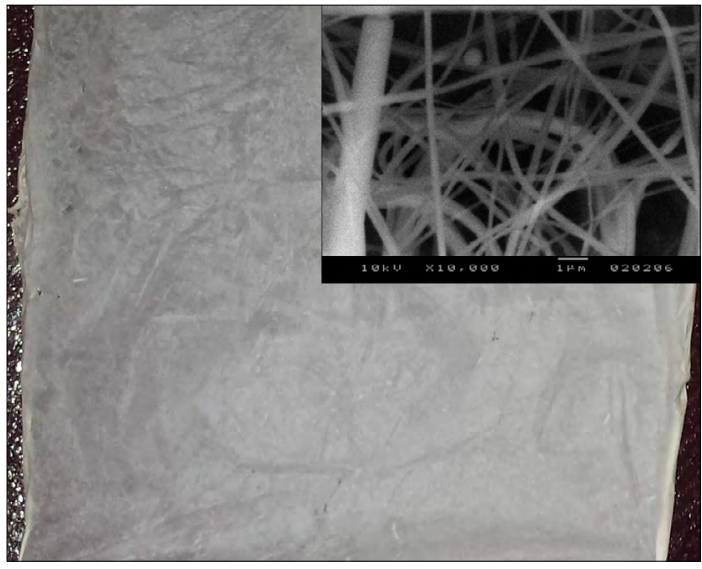

3. ábra. Porózus polimermembrán, valamint annak pásztázó elektronmikroszkóppal készített képe

PET-membrán fehér színű, nem átlátszó, és első megközelítésre vékony fóliához hasonlít. Viszont a pásztázó elektronmikroszkópos vizsgálat után egyértelműen látszik a porózus szerkezet, amit a PET-szálak nem szabályszerű egymásra helyezése eredményez.

\subsection{Kísérletek tervezése}

A PET-palackok elektrosztatikus szálképzéssel végzett újrahasznosítási folyamatának vizsgálatára szolgáló kísérletsorozat kísérleti változói az 1. táblázatban találhatók. A szálképzési folyamatot befolyásoló tényezők közül a PET-oldat tömegszázalékos koncentrációját (C), térfogatáramát (F), a tủ és a kollektor közti potenciálkülönbséget (V), a tű hegye és a kollektor közti távolságot (D) és a tű belső átmérőjének (ID) hatását vizsgáltuk a keletkezett szál átmérőjére.

Az egyes változók hatását egy adott beállításra vizsgáltuk, mint például:

- A V hatását az 1., 2. és 3. kísérlettel vizsgáljuk: $\mathrm{C}=10 \%, \mathrm{~F}=15 \mu \mathrm{L} / \mathrm{min}, \mathrm{D}=250 \mathrm{~mm}$ és $\mathrm{ID}=0,8 \mathrm{~mm}$, valamint $\mathrm{V}=15,20$ és $25 \mathrm{kV}$.

- Az F hatását a 2., 4. és 5. kísérlettel vizsgáljuk: $\mathrm{C}=10 \%, \mathrm{~V}=20 \mathrm{kV}, \mathrm{D}=250 \mathrm{~mm}$, ill. ID = 0,8 mm, valamint $F=15$, 30 és $45 \mu \mathrm{L} / \mathrm{min}$.

- A D hatását a 2., 8. és 9. kísérlettel vizsgáljuk: $\mathrm{C}=10 \%, \mathrm{~V}=20 \mathrm{kV}, \mathrm{F}=30 \mu \mathrm{L} / \mathrm{min}, \mathrm{ID}=0,8 \mathrm{~mm}$, valamint $D=200,250$ és $300 \mathrm{~mm}$.

1. táblázat. Az elektrosztatikus szálképzés folyamatának vizsgálatára irányuló kísérletek

\begin{tabular}{|c|c|c|c|c|c|c|c|}
\hline $\begin{array}{l}\text { Sor- } \\
\text { szám }\end{array}$ & $\underset{\text { (tömeg \%) }}{\mathrm{C}}$ & $\underset{(\mu \mathrm{L} / \mathrm{min})}{\mathbf{F}}$ & $\begin{array}{c}\mathrm{V} \\
(\mathrm{kV})\end{array}$ & $\underset{(\mathrm{mm})}{\mathrm{D}}$ & $\underset{(\mathrm{mm})}{\text { ID }}$ & $\begin{array}{c}\text { PET-szál átmérő } \\
\text { (nm) }\end{array}$ & $\begin{array}{c}\text { PET-gömb } \\
\text { átmérő } \\
(\mu \mathrm{m})\end{array}$ \\
\hline 1 & 10 & 15 & 15 & 250 & 0,8 & $289,6 \pm 98,8$ & $0 \pm 0$ \\
\hline 2 & 10 & 15 & 20 & 250 & 0,8 & $502,8 \pm 263,9$ & $0 \pm 0$ \\
\hline 3 & 10 & 15 & 25 & 250 & 0,8 & $452,4 \pm 165,6$ & $0 \pm 0$ \\
\hline 4 & 10 & 30 & 20 & 250 & 0,8 & $322,4 \pm 151,3$ & $9,73 \pm 4,40$ \\
\hline 5 & 10 & 45 & 20 & 250 & 0,8 & $359 \pm 112,5$ & $0 \pm 0$ \\
\hline 6 & 10 & 30 & 20 & 200 & 0,8 & $549,3 \pm 236,1$ & $0 \pm 0$ \\
\hline 7 & 10 & 30 & 20 & 300 & 0,8 & $407,1 \pm 169,9$ & $11,60 \pm 3,85$ \\
\hline 8 & 10 & 15 & 20 & 250 & 0,55 & $297 \pm 106,7$ & $7,69 \pm 2,42$ \\
\hline 9 & 10 & 15 & 20 & 250 & 0,3 & $377,4 \pm 138,8$ & $0 \pm 0$ \\
\hline 10 & 5 & 15 & 15 & 250 & 0,8 & $126 \pm 49$ & $4,5 \pm 1,3$ \\
\hline 11 & 5 & 15 & 20 & 250 & 0,8 & $0 \pm 0$ & $5,5 \pm 0,8$ \\
\hline 12 & 5 & 15 & 25 & 250 & 0,8 & $118 \pm 165,6$ & $3,5 \pm 1,1$ \\
\hline 13 & 5 & 30 & 20 & 250 & 0,8 & $283,5 \pm 192,2$ & $5,5 \pm 1,7$ \\
\hline 14 & 5 & 45 & 20 & 250 & 0,8 & $171 \pm 80,5$ & $4,2 \pm 2$ \\
\hline 15 & 5 & 30 & 20 & 200 & 0,8 & $295,9 \pm 225,8$ & $4,9 \pm 2,4$ \\
\hline 16 & 5 & 30 & 20 & 300 & 0,8 & $346 \pm 132,2$ & $5,9 \pm 2,1$ \\
\hline 17 & 5 & 15 & 20 & 250 & 0,55 & $159,7 \pm 92,2$ & $5,9 \pm 1,9$ \\
\hline 18 & 5 & 15 & 20 & 250 & 0,3 & $245,9 \pm 75,8$ & $0 \pm 0$ \\
\hline
\end{tabular}


- Az ID hatását a 4., 6. és 7. kísérlettel vizsgáljuk.: $\mathrm{C}=10 \%, \mathrm{~V}=20 \mathrm{kV}, \mathrm{F}=15 \mu \mathrm{L} / \mathrm{min}, \mathrm{D}=250 \mathrm{~mm}$, míg ID = 0,8, 0,55 és 0,3 $\mathrm{mm}$.

- A kísérletsorozatot 5., 10. és 15. tömeg-\%-os koncentrációra teszteltük, viszont a 15 tömeg\%-os oldatot a túlzottan nagy viszkozitása miatt nem lehetett felhasználni.

\subsection{A pásztázó elektronmikroszkópos mé- rés adatainak feldolgozása}

\subsubsection{A szálképzés változóinak hatása a szál átmérőjére}

A következőkben tárgyaljuk a szálképzési változók hatását a keletkezett PET-szál átmérőjére. Mind a négy vizsgált változó esetén a kísérleteket 5 és $10 \%$ koncentrációjú oldattal végeztük, így minden grafikonon a PET-oldat koncentrációjának hatását, ill. a tanulmányozott változó hatását lehet látni.

A 4. ábrán a potenciálkülönbség hatása látható a képzett PET-szál átmérőjére.

A 4. ábrán látható, hogy $\mathrm{C}=10 \%$ esetén az alkalmazott potenciálkülönbség növelésével növekszik a keletkezett PET-szál átmérője. $15 \mathrm{kV}$ esetén 289,6 \pm 98,8 nm átmérőjü PET-szálak keletkeztek, míg $25 \mathrm{kV}$ esetén 452,4 \pm 165,6 nm átmérőjüek. A $20 \mathrm{kV}$ potenciálkülönbség alkalmazása esetén kissé vastagabb PET-szálak keletkeztek, 502,8 \pm 263,9 nm átmérőjüek, viszont itt megjegyzendő, hogy a szórás ebben az esetben viszonylag nagy. Ezek az eredmények egyezésben vannak a szakirodalomban jelentett eredménnyel [10]. A szak-

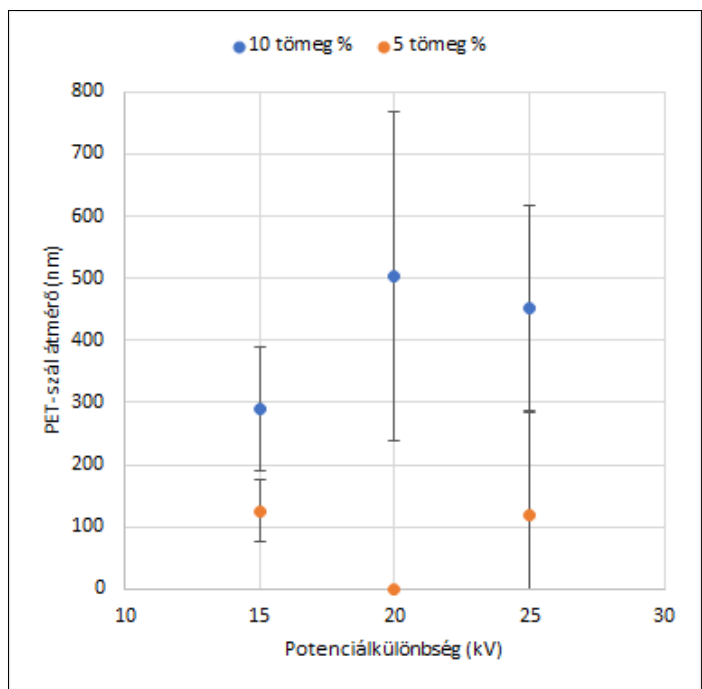

4. ábra. $A$ V hatása a PET-szál átméröjére $F=15 \mu \mathrm{L} /$ $\min , D=250 \mathrm{~mm}$, valamint $I D=0,8 \mathrm{~mm}$ esetén irodalom magyarázata szerint minél nagyobb a potenciálkülönbség, annál erősebb a keletkezett elektromos tér, amely több oldatot „húz ki” a tüből, így növekszik az egységnyi idő alatt kikerülő oldat mennyisége, és ez a keletkezett szál átmérőjének növekedéséhez vezet. C = 5\% esetén ez a jelenség nem annyira nyilvánvaló, viszont míg V = $15 \mathrm{kV}$ esetén a PET-szál-átmérője $126 \pm 49 \mathrm{~nm}$ volt, megjelentek gömbök a mintán, melyek átmérője 4,5 $\pm 1,3 \mu \mathrm{m} .20 \mathrm{kV}$ esetén minimális mennyiségü szál keletkezett, míg a gömb átmérője 5,5 \pm 0,8 $\mu \mathrm{m}$ volt. $25 \mathrm{kV}$ esetén szintén nagy mennyiségű gömb jelent meg, mind a szálon, mind a szálon kívül. A keletkezett szálak átlagos átmérőértéke $118 \pm$ 165,6 nm. A potenciálkülönbség hatása tehát csekély a keletkezett szálak átmérőjére $\mathrm{C}=5 \%$ esetén.

Az F hatása a keletkezett szál átmérőjére az 5. ábrán látható.

Az általános tendencia a szakirodalom szerint az, hogy a térfogatáram növelésével növekszik a keletkezett szál átmérője. Az 5. ábrán láthatók a kapott eredmények, melyekből kitűnik, hogy C = 10\% esetén a szakirodalomban jelentett szálátmérő-növekedés $F=30$ és $45 \mu \mathrm{L} /$ min esetén teljesül. Ennek a jelenségnek a magyarázata szintén viszszavezethető a polimeroldatból a folyadéksugárba kerülő anyag mennyiségére, vagyis nagyobb $\mathrm{F}$ esetén több PET van a folyadéksugárban. C = 5\% esetén a várt, növekvő szálátmérő a növekvő tömegárammal nem teljesül, viszont ezekben az esetekben csak minimális mennyiségű szál kelet-

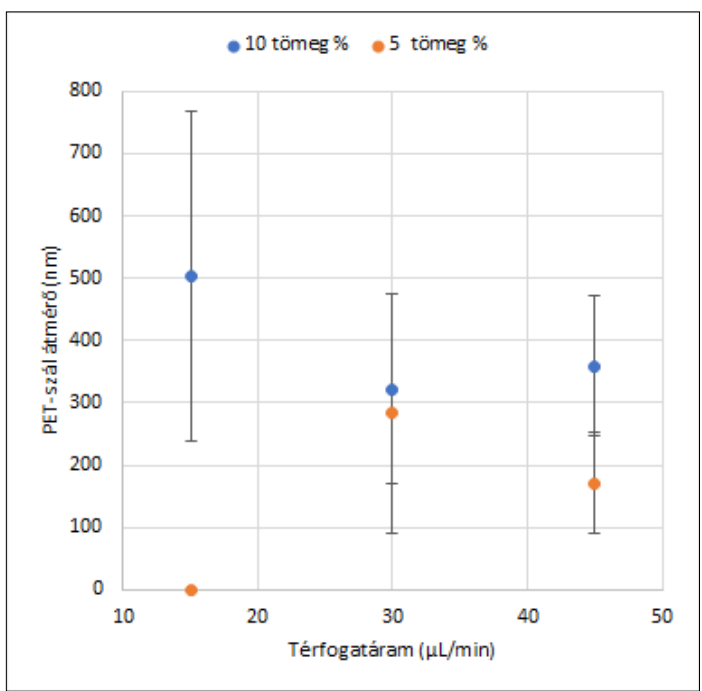

5. ábra. Az F hatása a képzett PET-szálak átmérőjére $20 \mathrm{~V}=k \mathrm{~V}, \mathrm{D}=250 \mathrm{~mm}$, valamint $\mathrm{ID}=0,8 \mathrm{~mm}$ tü esetén 
kezett, és inkább a gömbök képződése jellemző. A gömbök átmérője $5,5 \pm 0,8 \mu \mathrm{m}, 5,5 \pm 1,7 \mu \mathrm{m}$ és $4,2 \pm 2 \mu \mathrm{m} \mathrm{15}$, 30, ill. $45 \mu \mathrm{L} / \mathrm{min}$ esetén.

A D hatása a keletkezett szál átmérőjére a 6. ábrán látható.

A 6. ábrán látható, hogy $\mathrm{C}=10 \%$ mellett a szálátmérőnek van egy minimumértéke a D növelésének függvényében. $\mathrm{D}=200 \mathrm{~mm}$ elektródatávolság esetén 549,3 \pm 236,1 nm átmérőjü, míg $250 \mathrm{~mm}$ esetén $322,4 \pm 151,3 \mathrm{~nm}$ és $300 \mathrm{~mm}$ esetén 407,1 $\pm 169,9$ nm átlagos átmérőjű szálak keletkeztek. A szakirodalom alapján a kis elektródatávolság esetén az oldószernek nincs ideje az elpárolgásra, így „nedves” szálak keletkeznek, relatíve nagy átmérővel. Amint a távolságot növeljük, az oldószernek több ideje lesz elpárologni, és így kisebb átmérőjű szálak keletkeznek. A szakirodalom és az itt bemutatott eredmények közti különbség magyarázatát még kutatjuk.

$C=5 \%$ esetén hasonló tendencia látható, viszont ezekben az esetekben a gömbök megjelenése jellemző nagy számban. A gömbök átmérője mindhárom esetben hasonló, vagyis 5,9 $\pm 2,1 \mu \mathrm{m} \mathrm{D}=$ $200 \mathrm{~mm}, 5,5 \pm 1,7 \mu \mathrm{m} \mathrm{D}=250 \mathrm{~mm}$, ill. 5,9 $\pm 1,9 \mu \mathrm{m}$ $\mathrm{D}=300 \mathrm{~mm}$ esetén.

Az ID hatása a keletkezett PET-szál átmérőre a 7. ábrán látható.

A 7. ábrán megfigyelhető, hogy a kis ID nem eredményez kisebb szálátmérőt. Mindkét esetben - C = 5 és $10 \%$, a 0,3 mm átmérőjü tűnél keletkezett szálak átmérője, $245,9 \pm 75,8 \mathrm{~nm}$, illetve 377,4 $\pm 138,8 \mathrm{~nm}$, nagyobbak, mint a $0,55 \mathrm{~mm}$ átmérőjü

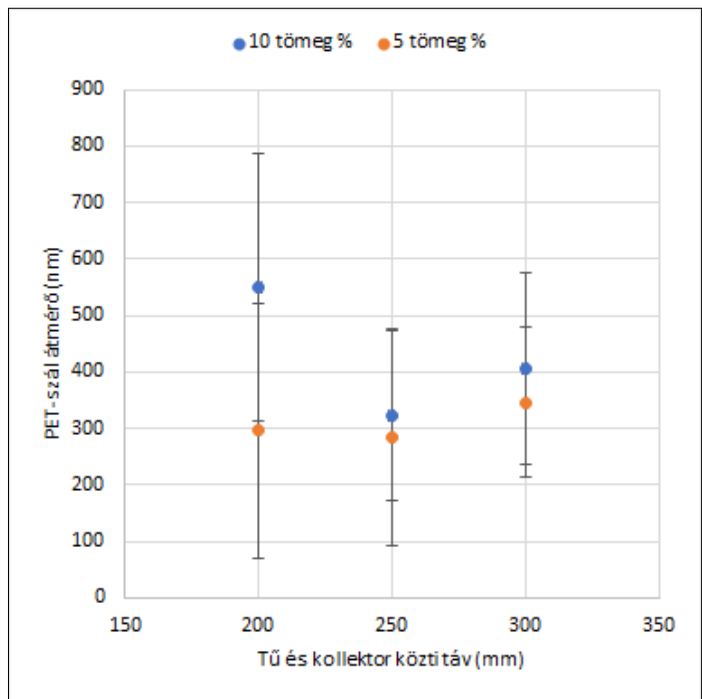

6. ábra. A D hatása a képzett PET-szál átmérőjére $V=20 \mathrm{kV}, F=30 \mu \mathrm{L} / \mathrm{min}$, valamint $\mathrm{ID}=0,8$ $\mathrm{mm}$ tü esetén tü esetén: 159,7 \pm 92,2 nm, illetve $297 \pm 106,7 \mathrm{~nm}$. Érdemes megjegyezni, hogy C $=5 \%$ és ID $=0,3 \mathrm{~mm}$ esetén nem jelentkeztek gömbök, míg minden más feltétel mellett igen, ennél a koncentrációnál. Érdekes módon a C $=5 \%$, ID $=0,8 \mathrm{~mm}$ esetén nem keletkeztek szálak, csak gömbök 5,5 $\pm 0,8 \mu \mathrm{m}$ átmérővel. Viszont $\mathrm{C}=10 \%$ és ID $=0,8 \mathrm{~mm}$ esetén nem jelentkeztek gömbök, ill. a keletkezett PETszál átmérője 502,8 $\pm 263,9 \mathrm{~nm}$.

Általános jelleggel kijelenthető a 4-7. ábrák alapján, hogy a keletkezett PET-szál átmérőjét a polimeroldat koncentrációja nagyban befolyásolja. Kiemelnénk, hogy a szakirodalomhoz hasonlóan a tapasztalatok gömbök megjelenését mutatják a kisebb oldatkoncentráció esetén.

\subsubsection{A szálképzési változók hatása a szálak- ból kialakuló termék pásztázó elektronmik- roszkópos felvételeire}

A kísérletekben kapott termékek vizsgálata azt bizonyítja, hogy az általunk újrahasznosítási céllal használt PET 5\%-os koncentrációjánál - egy kísérleti kombinációt leszámítva - gömbök képződése kíséri a szálak képződését, illetve egyes beállításoknál csak minimális mennyiségű szál keletkezik. A 10\% koncentráció esetén a 4-es, 7-es és 8-as kísérletekben jelentek meg gömbök a szálakból képződött termékben, viszont ezek nagy többsége magán a szálon található. Ez az eredmény megegyezik a szakirodalomban találtakkal, vagyis a koncentráció növelésével meg lehet akadályozni a gömbök megjelenését.

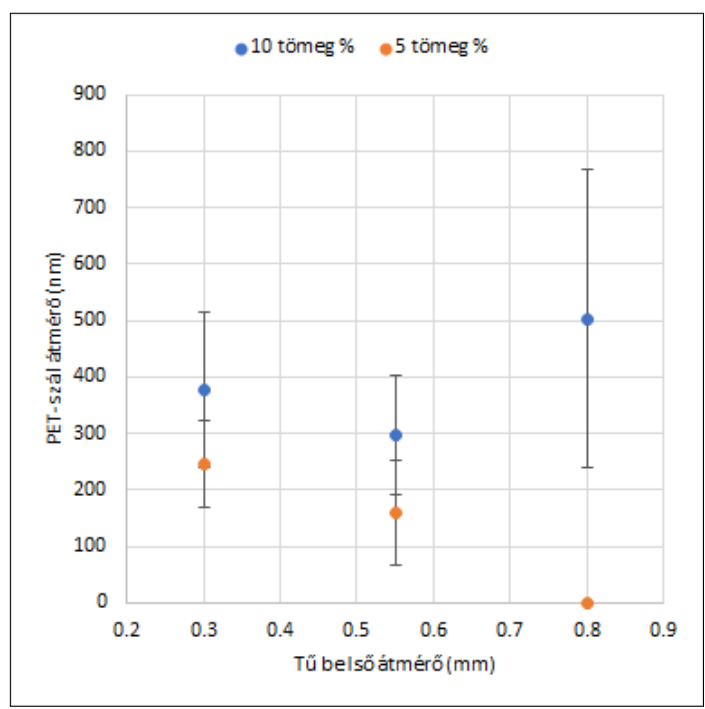

7. ábra. A tü ID-hatása a képzett PET-szál átmérőjére $V=20 \mathrm{kV}, F=15 \mu \mathrm{L} / \mathrm{min}, \mathrm{D}=250 \mathrm{~mm}$ esetén 


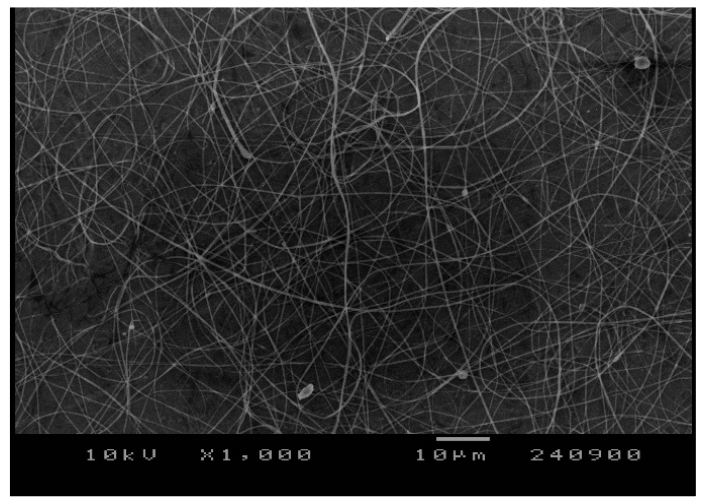

$\mathrm{C}=5 \%, \mathrm{ID}=0,3 \mathrm{~mm}$

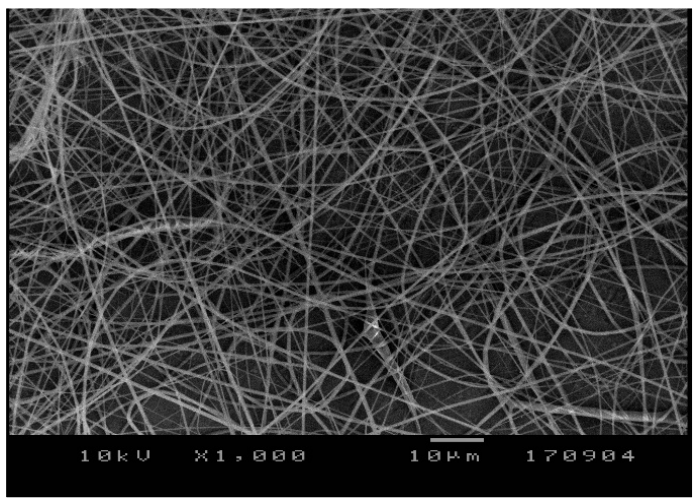

$\mathrm{C}=10 \%, \mathrm{ID}=0,3 \mathrm{~mm}$
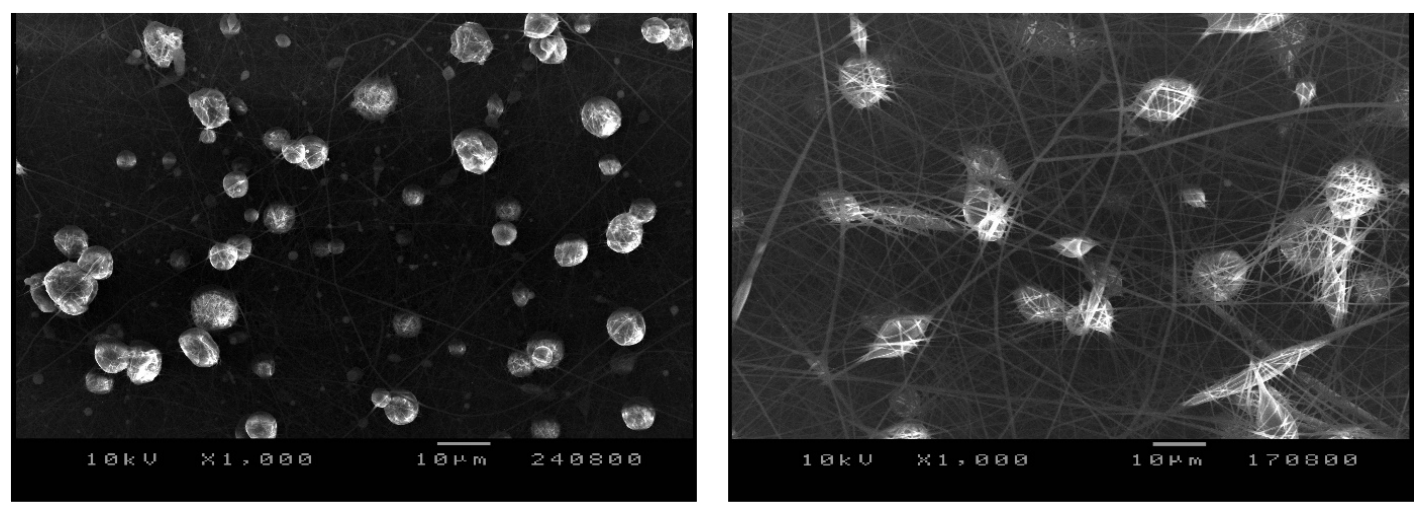

$\mathrm{C}=5 \%, \mathrm{ID}=0,55 \mathrm{~mm}$

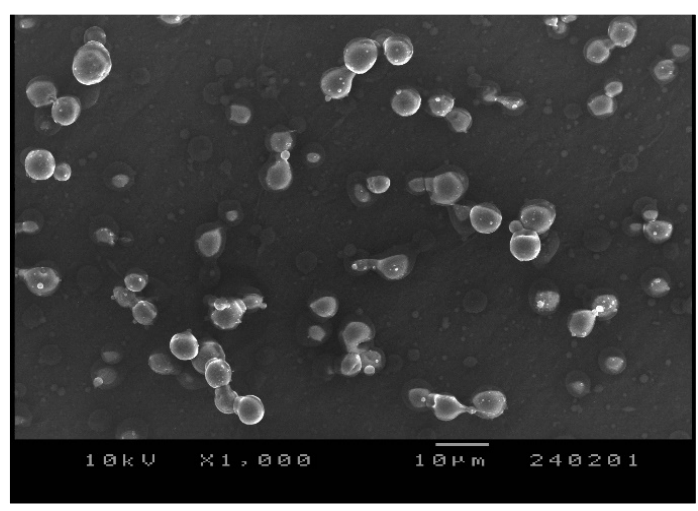

$\mathrm{C}=10 \%, \mathrm{ID}=0,55 \mathrm{~mm}$

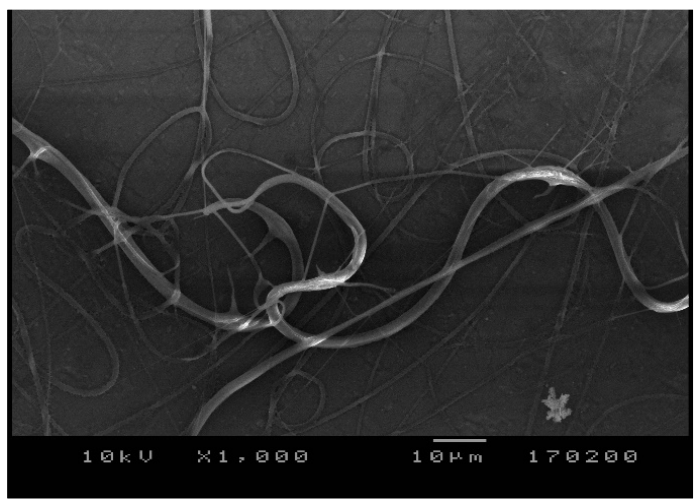

$\mathrm{C}=10 \%, \mathrm{ID}=0,8 \mathrm{~mm}$

8. ábra. PET-szálakból kialakított termék pásztázó elektronmikroszkópos felvételei az ID függvényében $C=5$ és $10 \%, V=20 \mathrm{kV}, F=15 \mu \mathrm{L} / \mathrm{min}$ és $D=250 \mathrm{~mm}$ esetén

A 8. ábrán látható a PET-szálakból kialakult termék pásztázó elektronmikroszkópos felvételeinek alakulása a tủ belső átmérőjének hatására $\mathrm{C}=5$ és $10 \%, \mathrm{~V}=20 \mathrm{kV}, \mathrm{F}=15 \mu \mathrm{L} / \mathrm{min}$, illetve $\mathrm{D}=250 \mathrm{~mm}$ esetén.

\section{Következtetések}

Következtetésként elmondható, hogy a tervezett szálképző berendezés alkalmas polimerszálak gyártására. Továbbá feltérképeztük a szálképzési 
tényezők hatását a Carpatica ásványvíz PET-palackjának újrahasznosításával előállított szálas anyagtermékre, melyek eredményei a szakirodalomban közölt eredményekkel kvalitatív szempontból egyeznek. Sikeresen állítottunk elő polimerszálakat 200 és $600 \mathrm{~nm}$ átmérők között. PET-nanoszálas termékeket hoztunk létre, melyeket filc, nemez vagy membrán állapotra hozva potenciálisan használhatunk szürési alkalmazásokban.

\section{Köszönetnyilvánítás}

Köszönjük dr. Jakab-Farkas László fizikusnak a pásztázó elektronmikroszkópos vizsgálatokban nyújtott segítségét. A kutatást a Sapientia Erdélyi Magyar Tudományegyetem Kutatási Programok Intézete (KPI) 13/14/17.05.2017 számú projekttel támogatta.

\section{Szakirodalmi hivatkozások}

[1] Khan W. S., Asmatulu R., Davuluri S., Dandin V. K.: Improving the Economic Values of the Recycled Plastics Using Nanotechnology Associated Studies. Journal of Materials Science \& Technology, 30/9. (2014) 854-859.

https://doi.org/10.1016/j.jmst.2014.07.006

[2] EPA U.S. Environmental Protection Agency, Wastes - Resource Conservation - Common Wastes \& Materials - Plastics.

http://www.epa.gov/osw/conserve/materials/ plastics.htm

[3] Welle F.: Twenty years of PET bottle to bottle recycling - an overview. Resources, Conservation and Recycling, 55/11. (2011) 865-875.

https://doi.org/10.1016/j.resconrec.2011.04.009

[4] Oromiehie A., Mamizadeh A.: Recycling PET beverage bottles and improving properties. Polymer International, 53/6. (2004) 728-732.

https://doi.org/10.1002/pi.1389

[5] Veleirinho B., Rei M. F., Lopes-Da-Silva J. A.: Solvent and concentration effects on the properties of electrospun poly(ethylene terephthalate) nanofiber mats. Journal of Polymer Science, Part B: Polymer Physics, 46/5. (2008) 460-471. https://doi.org/10.1002/polb.21380

[6] G. Li, Y. Zhao, M. Lv, Y. Shi, D. Cao: Super hydrophilic poly(ethylene terephthalate) (PET)/poly(vinyl alcohol) (PVA) composite fibrous mats with improved mechanical properties prepared via electrospinning process. Colloids and Surfaces A:
Physicochemical and Engineering Aspects, 436. (2013) 417-424.

https://doi.org/10.1016/j.colsurfa.2013.07.014

[7] Awaja F., Pavel D.: Recycling of PET. European Polymer Journal, 41/7. (2005) 1453-1477.

https://doi.org/10.1016/j.eurpolymj.2005.02.005

[8] Rajabinejad H., Khajavi R., Rashidi A., Mansouri N., Yazdanshenas M. E.: Recycling of used bottle grade poly ethyleneterephthalate to nanofibers by melt-electrospinning method. International Journal of Environmental Research and Public Health, 2009/3. 663-670.

[9] Anandjiwala R. D., Boguslavsky L.: Development of needle-punched nonwoven fabrics from flax fibres for air filtration applications. Textile Research Journal, 78. (2008) 614-624.

https://doi.org/10.1177\%2F0040517507081837

[10] Strain I. N., Wu Q., Pourrahimi A. M., Hedenqvist M.S., Olsson R. T., Andersson R. L.: Electrospinning of recycled PET to generate tough mesomorphic fibre membranes for smoke filtration. Journal of Materials Chemistry A, 3/5. (2015) 1632-1640. https://doi.org/10.1039/C4TA06191H

[11] Huang Z.-M., Zhang Y.-Z., Kotaki M., Ramakrishna S.: A review on polymer nanofibers by electrospinning and their applications in nanocomposites. Composites Science and Technology, 63/15. (2003) 2223-2253.

https://doi.org/10.1016/S0266-3538(03)00178-7

[12] Thompson C. J., Chase G. G., Yarin A. L., Reneker D. H. : Effects of parameters on nanofiber diameter determined from electrospinning model. Polymer, 48/23. (2007) 6913-6922.

https://doi.org/10.1016/j.polymer.2007.09.017

[13] Reneker D. H., Yarin A. L.: Electrospinning jets and polymer nanofibers. Polymer, 49/10. (2008) 2387-2425.

https://doi.org/10.1016/j.polymer.2008.02.002

[14] Athira K., Sanpui P., Chatterjee K.: Fabrication of Poly(Caprolactone) Nanofibers by Electrospinning. Journal of Polymer and Biopolymer Physics Chemistry, 2/4. (2014) 62-66.

[15] Taylor G. I.: Electrically driven jets. Proceedings of Royal Society A, 313/1515. (1969) 453-475.

https://doi.org/10.1098/rspa.1969.0205

[16] Zander N. E., Gillan M., Sweetser D.: Recycled PET Nanofibres for Water Filtration Applications. Materials, 9/4. (2016) 247-253. https://doi.org/10.3390/ma9040247 